\title{
The Phonoaesthetic Features in T.S. Eliot's Selected Poems
}

\author{
Asst. Prof. Qasim Abbas Dhayef \\ Department of English Language, University of Babylon, College of Education for Human Sciences, Babylon, Iraq
}

\author{
Asst. Lect. Omar Osama Nashaat \\ Directorate General of Teachers’ Training and Educaional Development, Baghdad, Iraq. oo8004880@gmail.com
}

\begin{abstract}
:
A comprehensive revision on literature, especially poetry, reveals that there is a very strong connection between poetry and phonology. This paper identifies the phonoaesthetic instances in poetry i.e., consonance and assonance in five selected poems written by T.S. Eliot who was the most prominent figure in English poetry.

This paper finds out the answers to questions behind the use of such features and the harmony and aesthetic value between the process of writing a poem and phonological features such as consonance and assonance whether they have been used intentionally or casually.

This paper shows that T.S. Eliot utilizes phonoaesthetic features i.e., consonance and assonance as stylistic features to add musicality and emphasis on certain phrases and words. It also confirms the hypothesis of this article that plosives consonants and close front vowels are heavily used and most frequently by (114) and (112) times for /s/ and /t/ and (77) and (85) times for /e/ and /i/.
\end{abstract}

Keywords: phonoaesthetic features, stylistics, phonology, consonance, assonance, plosives.

Article Received: 18 October 2020, Revised: 3 November 2020, Accepted: 24 December 2020

\section{Introduction}

Language is important for human beings. It is an essential tool for communication. People communicate their feelings and emotions through language. Human life thought to be depicted in literary works. According to Jacobson (1960: 365), language has six functions: referential, emotive, phatic, conative, metalingual and poetic. Accordingly, it can be concluded that the six functions of language enable humans to send and receive messages. One of these functions is 'poetic' which focuses on the message and it can be found in poetry.

Style is an essential element in literary works. Leech and short (2007:9) argue that the word style refers to the language use in certain context, by a certain person, for a certain purpose and so on. But the literary definition of the word style is how the writer transfer his/her thoughts into words.

Stylistics is a branch of linguistics in which concerned with the analysis of literary texts. In another word, it is the field which analyse literary text from linguistic perspectives. Some of the main devices which can be analyzed are syntactic, semantic, phonological and graphological.

As it is known, there is a strong connection between poetry and phonology. How the poem is organized and originated can help to understand its phonological aspects. Poetry in general, and T.S. Eliot in particular, connects literature with phonological features such as consonance and assonance to show the interwoven relations between the two disciplines.

The core of T.S. Eliot's poetry lies in the adaptation of phonological features such as assonance and consonance to reflect the poetic taste which satisfies both readers and listeners.

The paper seeks to argue the following questions:

1. What kind of consonance and assonance does T.S. Eliot utilize in his poetry?

2. How often (frequencies) does consonance and assonance utilize?

3. What are the effects of using such features?

The hypotheses assume that phonological features such as consonance and assonance are highly utilized in T.S. Eliot's poetry. For consonance, 
voiceless consonants are used more than other sounds. Voiceless consonants are frequently utilized rather than voiced. The purpose of using such features is to create a sense of authority and abruptness, hashed tone, lightness and quickness and soothing effect. For assonance, the close front vowels ad highly used for the purpose of emphasis and creating rhythm.

The aim of this article is to identify the theoretical and practical side of consonance and assonance for the reader and the way the poet organizes phonological features to reflect a message for listeners.

The paper is limited to five randomly selected poems by T.S. Eliot entitled: The Love Song of J. Alfred Prufrock, Portrait of a Lady, Preludes, Whispers of Immortality and Journey of the Magi. The importance of this study lies in the connection between literature and phonology concerning phonoaesthetic feature, i.e., consonance and assonance. It is hoped that this study will be with great value for the readers who are interested in literature and phonology.

\section{Review of Related Studies}

In this section, some previous studies on style of language which are contributed to this paper and help to develop some ideas on the topic. The first paper entitled 'John Keats's 'La Belle Dame Sans Merci': A Stylistic Analysis by Al Shawa (2015). In the analysis of the poem, the writer utilized a stylistic approach and decide to concentrate on the poem from four different angles of stylistics: phonological, morphological, grammatical and graphological. The writer noticed the adaptation of alliteration, assonance, meter, consonance, rhyme and repetition.

The second paper entitled 'Phonology and Stylistics': A Phonoaesthetic Study of Gray's 'Elegy Written in a Country Churchyard' by Bassey Garvey. The aim of this paper is to give a deep analysis of all phonoaesthetic devices in the poem such as consonance, alliteration, assonance, elision, rhyme and onomatopoeia that reinforce the meaning of the poem.
The third paper is 'Stylistic Analysis of Maya Angelou's Equality' by Isti'anah in 2017. In this research, the writer analysed four linguistic levels: semantic, grammatical, graphological and phonological.

The last paper entitled 'A Phonostylistic Analysis of William Blake's Poem: Cradle Song' by Fareed Hameed Al-Hindawi. The researcher analysed the poem stylistically to show the effect of phonological devices on poetic language. The findings of the study suggested the repetition of alliteration, assonance, consonance and rhyme are utilized in the poem for stylistic values.

\section{Phonetics, Phonology and Literature}

Phonetics and phonology are not independent disciplines, they are interrelated. Roca and Johnson (2000:1) gives a kind of distinction between sound as a sound, referring to phonetics, and sound structure, referring to phonology. For some scholars, sounds are either mental or physical and this can be regarded as a kind of differentiation between phonetics and phonology (Finch, 2000: 4-33). While others suggest that there is an overlap between the two fields saying that when talking about phonetics, we are mainly concerned with the production of speech sound that have meanings (Roach: 2002:58). This indicates that we are not only producing sound but they should be meaningful. Simpson (2004: 6) defined phonology as the potential meaning if sounds in spoken language. He (Ibid: 15) adds that phonology deals with sound patterns in literary works. Simpson (2005) said that literary works have many ways to be examined and analyzed. They can be studied and analyzed lexically, phonologically, grammatically and graphologically. All these are included within stylistics. In the study we are mainly concerned with phonology.

Stylistics, on the other hand, can be regarded as the analysis of stylistic features in literary works. Saporta (1969: 5) suggests that the language of poetry is different from ordinary language. For his poetic language is an art. Sounds have certain 
functions in poetic language. Short (1996: 5) suggests that studying and analyzing sentence structure at various levels, such as syntactical, semantical and phonological, has a benefit to understand the relations between those levels. Thornborrow and Wareing (1998: 5-43) propose some functions such as aesthetic enjoyment, break a convention, creativity in forms, emphasis or contrasts ... etc. Others suggest other effects of sounds in poetic language such as plosive sounds have a sense of abruptness or authority, sibilants have a hushed tone, breathy sound has a soothing effect and soft liquid sound has an effect of lightness. According to Verdonk (2002: 4), stylistics is the analysis of prominent features to identify their effects. Accordingly, it is important to say that language is essential ground to stylistic analysis because it is rich with forms, meanings structures and alike which can be regarded as a gate the interpretation. So the main concern of stylistics is to identify the links between description and meaning, meaning here represents interpretation.

Eventually, stylistics identify the themes of literary works as it had some levels of analysis such as grammar, sounds, textual structures and words. Among these levels is phonological level which analyzes the phonological features of literary texts especially in poems. According to Jeffries and McIntyre (2010:35) argue that the major role of stylistics is to scrutinize the phonological aspects of poetic language.

\section{Consonants vs. Vowels}

Consonants can be defined both phonetically and phonologically. According to Crystal (2009: 103), consonant is a type of sound which can be produced when there is a complete closure or narrowing in the air flow. While phonologically, it is the segment that takes the marginal place in the syllable (Trask, 1996:87).

Some of the scholars depended on the idea of 'voicing' as a fundamental cornerstone of consonants which refers to the distinction between consonants based on whether voiced or voiceless
(Gimson, 1985: 25). Other scholars suggested some similar terms on consonants such as fortis and lenis (Knutsson, 2006: 1).

Vowels on the other hand, they are types of sound which produced without any closure or narrowing in the airflow and the air escape freely though the center of the tongue (Crystal, 2009: 517). Phonologically, vowels are the kinds of sounds which function as the core of the syllable (Ibid).

\section{T.S. Eliot and Phonological Features}

The modern poets achieve the musical effects of their poems by applying phonological features (parallelism). T.S. Eliot is among the poets who employs phonological features, or what is sometimes called 'phonological parallelism' for certain purposes.

Phonological parallelism comprised of certain features such as alliteration, assonance, consonance, rhyme, meter and rhythm. T.S. Eliot uses consonance and assonance to promote his language and distinct it from ordinary one. Parallelism is a vital tool in stylistics. It is utilized according to the writer's mental and emotional status (Chapman, 1973:80). It is a kind of foregrounding and deviation from the norms to serve prominence (Rabah,1997:130).

One of the phonological parallelism is consonance. Functionally, it is regarded as alliteration, but while alliteration is the repetition of the initial consonant sound, consonance is the repetition of the final consonant sound. This was supported by Madden (2002:70) and Arp and Johnson (2009:820) who clarify that consonance is the repetition of final consonant sound in a couple of words.

e.g. Or to take arms against a sea of troubles, so in this example, the repetition of final /s/ sound is a kind of consonance.

The second type of phonological features is assonance. While consonance is the repetition of final consonants, assonance is the repetition of the same vowel sound with the neighboring words. Bradford (2005: 16) defines assonance as the 
repetition of a series of similar vowels in the same line.

e.g. Once upon a midnight dreary, while I pondered, weak and weary.

\section{Method of the Study}

Consonance and assonance are easily to be noticed and according to Lefevere (1992:58) there is a reason behind the use of such features which is to add an aesthetic taste to poetic language. The five poems were taken from 'T.S. Eliot Collected Poems (1909 - 1962)' and are analyzed according to (1) consonance and (2) assonance.

\section{Data Analysis}

This paper conducted an eclectic model of analysis developed by this paper. This kind of model is based on phonetic apparatus in connection with phonoaesthetic study which is the essential core of this study. The paper is mainly concerned with the phonoaesthetic features such as consonance and assonance (shown in Fig. 1) which are the phonetic devices manifest themselves in the study. The method of presenting phonoaesthetic devices represented in the model which planned to be used to analyse the data under investigation. Furthermore, the study used statistical method and percentages to calculate consonance and assonance sounds.

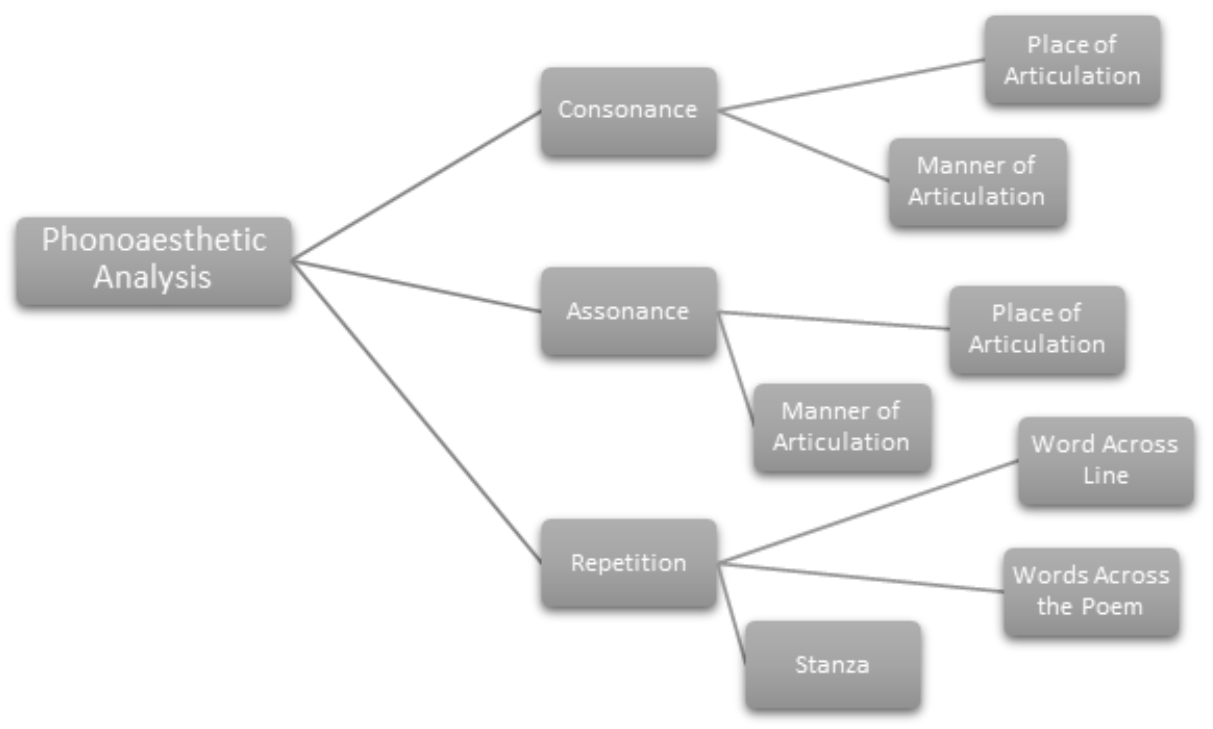

Figure. 1 The Eclectic Model of Analysis

\section{Consonance}

It is the first phonoaesthetic feature which is the repetition of the same word-ending consonant sounds. Examples, frequencies and percentages are illustrated in table (1)

Table (1) illustrates the total frequency of consonance sounds and Percentages utilized in the five randomly selected poems by T.S. Eliot

\begin{tabular}{|c|c|c|c|c|c|c|c|c|c|c|c|}
\hline Poem & $/ \mathrm{t} /$ & $/ \mathrm{s} /$ & $/ \mathrm{n} /$ & $/ \mathrm{d} /$ & $/ \mathrm{m} /$ & $/ \mathrm{g} /$ & $/ \mathrm{l} /$ & $/ \mathrm{ts} /$ & $/ \mathrm{k} /$ & $/ \theta /$ & $/ \mathrm{p} /$ \\
\hline $\begin{array}{c}\text { The Love } \\
\text { Song of J. } \\
\text { Alfred } \\
\text { Prufrock }\end{array}$ & 64 & 50 & 38 & 23 & 17 & 14 & 9 & $/$ & $/$ & $/$ & $/$ \\
\hline $\begin{array}{c}\text { The } \\
\text { Portrait of }\end{array}$ & 32 & 32 & 13 & 16 & 4 & 4 & 7 & 2 & 4 & $/$ & $/$ \\
\hline
\end{tabular}




\begin{tabular}{|c|c|c|c|c|c|c|c|c|c|c|c|}
\hline a Lady & & & & & & & & & & & \\
\hline Preludes & 10 & 12 & 4 & 10 & I & 4 & 2 & I & I & I & / \\
\hline $\begin{array}{l}\text { Whispers } \\
\text { of } \\
\text { immortalit } \\
y\end{array}$ & I & 10 & 2 & 4 & I & I & 2 & I & I & I & I \\
\hline $\begin{array}{c}\text { Journey of } \\
\text { the Magi }\end{array}$ & 6 & 10 & 16 & 11 & I & 10 & I & I & I & 7 & 2 \\
\hline Total & $\begin{array}{c}112 \\
24.8 \\
\%\end{array}$ & $\begin{array}{c}114 \\
25.2 \\
\%\end{array}$ & $\begin{array}{c}73 \\
16.1 \\
\%\end{array}$ & $\begin{array}{c}64 \\
14.1 \\
\%\end{array}$ & $\begin{array}{c}21 \\
4.6 \%\end{array}$ & $\begin{array}{l}32 \\
7 \%\end{array}$ & $\begin{array}{c}20 \\
4.4 \%\end{array}$ & $\begin{array}{c}2 \\
0.4 \%\end{array}$ & $\begin{array}{c}4 \\
0.8 \%\end{array}$ & $\begin{array}{c}7 \\
1.5 \%\end{array}$ & $\begin{array}{c}2 \\
0.4 \%\end{array}$ \\
\hline
\end{tabular}

One can notice that /t/ and /s/ sounds are frequently used in the five selected poems. According to the distinctive feature of $/ \mathrm{s} /$ sound it is +consonantal, +anterior, +coronal, +continuant and + sibilant. The distinctive feature of $/ \mathrm{t} /$ sound is +consonantal, +anterior and +Coronal. The table above found out that the voiceless sounds are highly occurred more than other types /t/ sounds occurred (112) with $24.8 \%$ while /s/ sound occurred (114) times with $25.2 \%$. The /s/ sound is functioned as an aesthetic feature to indicate quickness, slyness, smoothness and to create the atmosphere of tranquility. While / $\mathrm{t} /$ sound is hard and plosive which gives the feeling of abruptness and authority. Consonance is widely used in T.S. Eliot's poems for several reason: to create a specific mood, to give a sense of musicality, create smoothness and feeling of abruptness.

\subsection{Assonance}

Assonance is the repetition of the same vowel in two or more words in the same line. This occurrence is so-called 'assonance'. Table (2) illustrates frequencies and percentages in these five selected poems by T.S. Eliot.

Table (2) illustrates the total frequency and percentage of assonance sounds utilized in the five abovementioned poems by T.S. Eliot

\begin{tabular}{|l|c|c|c|c|c|}
\hline \multicolumn{1}{|c|}{ Poem } & /e/ & /i/ & /i:/ & /ei/ & /ai/ \\
\hline $\begin{array}{l}\text { The Love Song of J. Alfred } \\
\text { Prufrock }\end{array}$ & 33 & 28 & 18 & 6 & 12 \\
\hline The Portrait of a Lady & 19 & 35 & 19 & 8 & 5 \\
\hline Preludes & 2 & 4 & 6 & 4 & $/$ \\
\hline Whispers of immortality & 9 & 12 & $/$ & $/$ & 2 \\
\hline Journey of the Magi & 14 & 6 & 6 & 3 & 4 \\
\hline Total & 77 & 85 & 49 & 21 & 23 \\
$(30.1 \%)$ & $(33.3 \%)$ & $(19.2 \%)$ & $(8.2 \%)$ & $(9 \%)$ \\
\hline
\end{tabular}

The analysis of assonance shows that close, front and unrounded vowels and highly utilized in the above-mentioned tables. /e/ sound is close-mid, front and unrounded vowel while /i/ sound is near close, near front and unrounded vowel. One can notice that /i/ sound is highly frequent with (85) times, equals (33.3\%). The vowel /e/ comes in the second place with (77) times, equals (30.1\%) and /i:/ vowel comes in the third lace with (49) times, equals (19.25). These kinds of vowels are utilized in T.S. Eliot's poems for the following reasons: (1) to add emphasis through highlight certain words and visualize them in order to draw readers' attention towards these words, (2) to create rhythm by adding musicality, back up the tone of the poem and make words captivating in 
which they can be stick to the mind for a long time.

\section{Results}

According to the analysis of the poems above, it is found that there are many instances where consonance and assonance are obviously prominent. The results of the study can be briefly presented as follows:

1. In poem 'the Love Song of Alfred Prufrock' the consonance utilized in the following sounds: /t/ sound is highly frequent by (64) reps, /s/ sound with (50) reps, /n/ with (38) reps and /d/ sound with (23) reps. while the assonance presents in the following sound: /e/ with (33) reps, /i/ sound with (28) and /i:/ sound with (18) reps.

2. In poem 'Portrait of a Lady', the consonance utilized as follows: / $/$ / and /s/ consonants are repeated (32), /d/ repeated (16) and /n/ repeated (13) times. While assonance utilized as follows: /i/ repeated (35) times, while /e/ and /i:/ repeated (19) times.

3. In poem 'Preludes', consonance represented as follows: /s/ repeated (12) times, /t/ and /d/ consonants repeated (10) times for both. While assonance represents as follows: /i:/ repeated (6) times, /i/ repeated (4) times and /e/ repeated twice.

4. I poem 'Whisper of Immortality', consonance represents as follows: /s/ repeated (10) times, /d/ repeated (4) times and $/ \mathrm{n} /$ twice. While assonance represents as follows: /i/ repeated (12) times and /e/ repeated (9) times.

5. In poem 'Journey of the Magi', consonance represents as follows: /t/ repeated (6) times, /s/ repeated (10) times, $/ \mathrm{n} /$ repeated (16) times, $/ \mathrm{d} /$ repeated (11) times and /g/ (10) times. While assonance represents as follows: /e/ repeated (14) times, /i/ repeated (6) times and /i:/ repeated (6) times.

6. Consonance is highly represented in sound /s/ with (114) times and /t/ with (112) times. While assonance is highly represented in sound /e/ with (77) times and /i/ with (85) times.

\section{Conclusion}

Issues on consonance and assonance are tested in this research and it could be summarized as follows:

1. Theoretically and as poetic language is essentially relay on auditory criterion, accordingly, phonoaesthetic devices such as consonance and assonance can be recognized by poetry listeners.

2. Practically, the analyzed data has revealed the following:

a. Through the analysis of the five randomly selected poems by T.S. Eliot, instances of consonance are found such as: /t/, /s/, /n/, $/ \mathrm{d} /, / \mathrm{m} /, / \mathrm{g} /, / \mathrm{l} /, / \mathrm{t} \mathrm{f} /$ and $/ \mathrm{k} /$. while instances of assonance can be found such as: /e/, /i/, /i:/, /ei/ and /ai/.

b. The analyzed data reveals that voiceless plosive consonants are highly illustrative examples of consonance such as: /s/ and /t/ and voiced consonants are less employed such as: /n/, /d/, /g/, /m/ and /l/.

c. The analyzed data reveals that close, front and unrounded vowels such as /e/ and /i/ are highly utilized than other kinds of vowels.

d. The analyzed data suggests that the effect of using the phonoaesthetic features such as consonance is for quickness, slyness, smoothness and to create the atmosphere of tranquility. In addition, to create a specific mood, to give a sense of musicality and to create smoothness and feelings of abruptness.

e. While the effect of using the phonoaesthetic feature of assonance is to add emphasis by highlighting words and visualize them in order to be prominent to the readers and memorable for a long time. In addition, to create rhythm by adding musicality and support the tone of the poem. 
f. In addition, the data reveals that according to the phonological feature of consonance, the two consonant $/ \mathrm{t} /$ and $/ \mathrm{s} /$ are highly utilized by (112) and (114) reps. while the assonance phonological feature reveals that the vowels /e/ and /i/ are highly utilized by (77) and (85) reps.

\section{References}

[1] Arp, Thomas R. \& Greg Johnson. (2009) Perrine's Literature Structure, Sound \& Sense $\left(5^{\text {th }}\right.$ ed). Boston: Wadsworth Cengage Learning. Cambridge University Press.

[2] Carter, Ronald \& Paul Simpson. (2005). Language, Discourse, and Literature. New York: Routledge.

[3] Chapman, R. (1973). Linguistics and Literature. London: Edward Arnold.

[4] Crystal, David. (2008). A Dictionary of Linguistics and Phonetics. Oxford: Blackwell Publishing LTD.

[5] Eliot, T. S. (1963). T.S. Eliot Collected Poems 1909 - 1962. New York: Harcourt, Brace and World Inc.

[6] Finch, G. (2000). Linguistic Terms and Concepts. New York: Macmillan Ltd.

[7] Gimson, A. (1985) An Introduction to the Pronunciation of English. London: Edward Arnold.

[8] Jakobson, Roman. (1960). Linguistics and poetics. In T. Sebeok (ed) (1960). Style in Language. Cambridge: M.I.T. Press.

[9] Jeffries, Lesley \& Dan McIntyre. (2010). Stylistics. Cambridge: Cambridge University Press

[10] Knutsson, P. (2006). Phonetics. http://www.hi.is/ KENNSLA/oz/oz-html.

[11] Leech, G. \& M. Short. (2007). Style in Fiction: An Introduction to English Fictional Prose ( $2^{\text {nd }}$ ed). London: Pearson Education Limited.

[12] Lefevere, A. (1992). Translating Literature: Practice \& Theory in Comparative Literature Context. New
York: The Modern Language Association of America.

[13] Madden, Frank. (2002). Exploring Poetry. London: Longman.

[14] Rabah, F. (1997)."Linguistic Deviation in Literary Translation". Unpublished Ph. D. Dissertation. Al-Mustansiriya University.

[15] Roach, P. (2000). English Phonetics and Phonology: A Practical Course. Cambridge:

[16] Roca, I. and Johnson, W. (2000). A Course in Phonology. London: Blackwell.

[17] Saporta, S. (1960). "The Application of Linguistics to the Study of Poetic Language" in Thomas Sebeok (ed.). Style in Language. Cambridge: Cambridge University Press.

[18] Short, M. (1996). Exploring the Language of Poems, Plays and Prose. London: Longman

[19] Simpson, Paul. (2004). Stylistics. New York: Routledge.

[20] Thornborrow, J. and Wareing, Sh. (1998). Patterns in Language: An Introduction to Language and Literary Style. London: Routledge.

[21] Trask, R. (1996). A Dictionary of Phonetics and Phonology. London: Ronald.

[22] Varshney, R. ( 1991). An Introductory Textbook of Linguistics \& Phonetics. Bareilly: Student Store.

[23] Verdonk, Peter. (2002). Stylistics. Oxford: Oxford University Press. 